\title{
Urgensi Larangan Kosmetik Terhadap Lingkungan Laut Pada Wisata Bahari
}

\section{The Urgency of the Prohibition of Cosmetics on the Marine Environment in Marine Tourism}

\author{
Andre Monifa \\ andremonifa@gmail.com
}

Fakultas Hukum Universitas Lampung

Submitted: Mar 2, 2020; Reviewed: Mar 24, 2020; Accepted: Apr 27, 2020

\begin{tabular}{|c|c|}
\hline Info Artikel & Abstrak \\
\hline $\begin{array}{l}\text { Kata Kunci: Urgensi; Larangan; Tabir } \\
\text { Surya. } \\
\text { Keywords: } \quad \text { Urgency; Prohibition; } \\
\text { Sunscreen. }\end{array}$ & $\begin{array}{l}\text { Kemajuan wisata laut memiliki dampak positif } \\
\text { bagi masyarakat lokal dan juga memberikan } \\
\text { kekhawatiran pada efek negatif terhadap } \\
\text { terumbu karang. Kerusakan terumbu karang di }\end{array}$ \\
\hline $\begin{array}{l}\text { DOI: } \\
\text { https://doi.org/10.25041/aelr.v1i1.2075 }\end{array}$ & $\begin{array}{l}\text { Indonesia saat ini mencapai } 46 \text { persen. } \\
\text { Kerusakan mengubah terumbu karang menjadi } \\
\text { putih dan mengancam keanekaragaman hayati } \\
\text { dan fungsi ekosistem terumbu karang. Salah } \\
\text { satu penyebab kerusakan adalah kandungan } \\
\text { oksibenzon dan octinoxate pada tabir surya yang } \\
\text { digunakan oleh para wisatawan laut. Hawaii } \\
\text { telah menerbitkan undang-undang tentang } \\
\text { larangan lotion tabir surya yang mengandung } \\
\text { zat-zat ini. Tujuan dari penelitian ini adalah } \\
\text { untuk menganalisis urgensi pelarangan tabir } \\
\text { surya di kawasan wisata laut di Indonesia } \\
\text { sebagai dasar penyusunan peraturan untuk } \\
\text { melindungi ekosistem terumbu karang. } \\
\text { Penelitian ini menggunakan pendekatan } \\
\text { yurisdiksi normatif dan menganalisis data } \\
\text { sekunder seperti teori hukum, peraturan } \\
\text { perundang-undangan, dan didukung oleh } \\
\text { beberapa penelitian tentang terumbu karang. }\end{array}$ \\
\hline
\end{tabular}


Hasil penelitian ini menunjukkan bahwa tabir surya mampu melindungi kulit dari paparan sinar ultraviolet yang dapat menyebabkan gangguan kesehatan akut dan kronis. Namun penggunaan oxybenzone dan octinoxate sebagai filter kimia juga berpotensi menyebabkan gangguan kesehatan. Zat-zat ini juga menyebabkan pemutihan terumbu karang bahkan pada tingkat penyelesaian terendah. Penggunaan tabir surya telah diatur di beberapa tempat di dunia. Mengacu pada teori hukum progresif, larangan menggunakan tabir surya yang mengandung oksibenzon dan octinoxate di kawasan wisata laut dianggap mendesak karena bentuk hukum yang dibuat untuk kesejahteraan manusia dan itu menjadi solusi bagi ketidakhadiran hukum mengenai perlindungan terumbu karang di Indonesia. Adaptasi hukum selektif dan bertanggung jawab yang didasarkan pada fakta dan data lingkungan hidup sesuai dengan teori hukum responsif.

\begin{tabular}{l} 
Abstract \\
The advancement of marine tourism has a \\
positive impact on local communities and also \\
raises concerns about negative effects on coral \\
reefs. Damage to coral reefs in Indonesia \\
currently reaches 46 percent. The damage turns \\
coral reefs white and threatens biodiversity and \\
the function of coral reef ecosystems. One of the \\
causes of damage is the oxybenzone and \\
octinoxate content in sunscreens used by marine \\
tourists. Hawaii has issued a law banning \\
sunscreen lotions containing these substances. \\
The purpose of this study was to analyze the \\
urgency of banning sunscreens in marine \\
tourism areas in Indonesia as a basis for \\
drafting regulations to protect coral reef \\
ecosystems. This study uses a jurisdictional \\
normative approach and analyzes secondary \\
data such as legal theory, laws and regulations, \\
and is supported by several studies on coral \\
reefs. The results of this study indicate that \\
sunscreen can protect the skin from exposure to \\
ultraviolet rays which can cause acute and \\
chronic health problems. However, the use of \\
oxybenzone and octinoxate as chemical filters \\
also has the potential to cause health problems. \\
These substances also cause coral bleaching \\
\hline
\end{tabular}


even at the lowest settlement level. The use of sunscreen is regulated in several parts of the world. Referring to the progressive legal theory, the prohibition of using sunscreens containing oxybenzone and octinoxate in marine tourism areas is considered urgent because the form of the law is made for human welfare and it is a solution to the absence of laws regarding the protection of coral reefs in Indonesia. Adapt selective and responsible law based on facts and environmental data in accordance with responsive legal theory.

\section{A. Pendahuluan}

Indonesia merupakan negara kepulauan terbesar kedua dengan garis pantai terpanjang di dunia setelah Kanada dengan garis pantainya mencapai $99.093 \mathrm{~km} .{ }^{1}$ Dengan keadaan geografis tersebut, Indonesia memiliki potensi yang sangat besar dalam bidang wisata bahari. Kawasan wisata bahari Indonesia yang mendunia ialah Pulau Bali. Selain itu, wisata bahari merupakan sektor andalan di Indonesia dengan jumlah pengunjung yang meningkat setiap tahunnya. Dari laporan yang dirilis oleh Dinas Pariwisata Provinsi Bali, jumlah kunjungan wisatawan asing pada tahun 2015 mencapai 4.001.835 orang. Jumlah ini meningkat pada tahun 2016, menjadi 4.927 .937 orang. $^{2}$ Sedangkan untuk wisatawan nusantara (lokal), jumlah kunjungan pada tahun 2015 sebanyak 7.147 .100 orang, kemudian meningkat pada tahun 2016 menjadi 8.643.680 orang. ${ }^{3}$ Menurut Kepala Dinas Pariwisata Bali, A.A. Yuniartha Putra, wisatawan mancanegara yang datang ke Bali sepanjang tahun 2017 mencapai 5,7 juta turis, meningkat $16 \%$ dari tahun $2016 .^{4}$

Kemajuan wisata bahari memberikan dampak positif diantaranya meningkatnya pendapatan masyarakat setempat, terbukanya lapangan pekerjaan baru serta peningkatan kualitas infrastruktur dan fasilitas umum di daerah tersebut. ${ }^{5}$ Namun, perkembangan wisata bahari juga disertai dengan kekhawatiran akan dampak negatif terhadap lingkungan. Salah satu ancaman yang timbul adalah kerusakan terumbu karang. ${ }^{6}$ Menurut Kepala Badan Karantina Ikan Pengendalian Mutu dan Keamanan Hasil Perikanan (BKIPM), kerusakan terumbu karang di Indonesia mencapai 46 persen. ${ }^{7}$ Di Provinsi Bali, kerusakan terumbu

\footnotetext{
${ }^{1}$ Marboen, A. P. (2015, Maret 27). Garis Pantai Indonesia Terpanjang Kedua di Dunia. Dipetik Juni 4, 2018, dari www.antaranews.com: https://www.antaranews.com/berita/487732/garis-pantai-indonesia-terpanjang-kedua-di-dunia

${ }^{2}$ Dinas Pariwisata Provinsi Bali. (2016). The Best Direct Foreign Tourist Arrival to Bali in January-December 2016. Denpasar: Dinas Pariwisata Provinsi Bali.

${ }^{3}$ Dinas Pariwisata Provinsi Bali. (2016). Pertumbuhan Kunjungan Wisnus Tahun 2016. Denpasar: Dinas Pariwisata Provinsi Bali.

${ }^{4}$ Antara, A. (2018, Januari 27). Jumlah Kunjungan Turis ke Bali Capai 5,7 Juta Orang. Dipetik Mei 11, 2018, dari www.lifestyle.okezone.com: https://lifestyle.okezone.com/read/2018/01/27/406/1850973/jumlah-kunjungan-turis-ke-balicapai-5-7-juta-orang

${ }^{5}$ Ernawati, N. M., "Pengaruh Pariwisata terhadap Kehidupan Sosial Budaya Pesisir". Jurnal Sabda, Vol. 6, No. 1, (2011), hlm 69-74.

6 Marcela Apriliani Lawang, "Penegakan Hukum Terhadap Pencemaran dan Perusakan Lingkungan Objek Wisata Berdasarkan Undang-Undang Nomor 10 Tahun 2009”, Jurnal Lex Crimen, Vol 4 No. 7, (2015), hlm 59.

${ }^{7}$ Antara, CNN Indonesia. (2017, Agustus 29). Kerusakan Terumbu Karang di Indonesia Mencapai 46 Persen. Dipetik Mei 11, 2018, dari Web site CNN Indonesia: https://www.cnnindonesia.com/gaya-hidup/20170829125301-269238068/kerusakan-terumbu-karang-di-indonesia-mencapai-46-persen
} 
karang sudah mencapai 12 persen dari luasan 7.200 hektare, sebagaimana diungkapkan oleh Gede Suarjana, Kepala Badan Lingkungan Hidup Provinsi Bali. ${ }^{8}$

Coral Bleaching atau pemutihan karang adalah suatu bentuk kerusakan terumbu karang. Fenomena ini berdampak negatif bagi keragaman hayati dan fungsi ekosistem terumbu karang tersebut. ${ }^{9}$ Jika dibiarkan, pemutihan karang dapat menyebabkan stress pada terumbu karang diikuti dengan kematian. ${ }^{10}$ Pemutihan terumbu karang erat hubungannya dengan kenaikan suhu air laut (anomali temperatur), radiasi tinggi, polusi serta penyakit yang disebabkan bakteri. ${ }^{11}$ Belakangan diketahui bahwa produk perawatan diri (kosmetik) pun berdampak buruk terhadap kualitas terumbu karang, termasuk tabir surya. ${ }^{12}$ Tabir surya merupakan bahan kimia yang terkandung di dalamnya akan ikut terbilas oleh air laut dan mengendap serta membahayakan ekosistem laut. National Geographic menyatakan bahwa beberapa bahan kimia dalam tabir surya dapat membangkitkan virus yang tidak aktif dalam algae Zooxanthellae. Pada keadaan normal, virus ini dibutuhkan oleh terumbu karang untuk melakukan fotosintesis. Dengan adanya bahan kimia tersebut, virus pada Zooxanthellae berkembang biak dengan cepat dan pada akhirnya mengakibatkan kerusakan terumbu karang yang ada di sekitarnya. ${ }^{13}$

Pada tanggal 1 Mei 2018, Hawaii melakukan gebrakan menjadi satu-satunya negara bagian Amerika Serikat yang berhasil meloloskan rancangan undang-undang berisi larangan distribusi tabir surya berbahan aktif oxybenzone dan octinoxate yang akan berlaku efektif sejak tanggal 1 Januari 2019. ${ }^{14}$ Peraturan tersebut juga menjadi undang-undang pertama di dunia yang melarang tabir surya berkandungan oxybenzone dan octinoxate digunakan di daerah wisata bahari. ${ }^{15}$ Langkah pemerintah Hawaii dalam melakukan pengaturan terhadap tabir surya merupakan upaya preventif dalam melindungi terumbu karang dari kerusakan. Langkah serupa belum diterapkan di Indonesia, hal ini akan berakibat buruk jika tidak segera dilakukan pengaturan larangan tabir surya berkandungan oxybenzone dan octinoxate akan menurunkan kualitas terumbu karang di kawasan wisata bahari. Bahkan, potensi kerusakan dapat terjadi akibat coral bleaching. ${ }^{16}$ Berdasarkan identifkasi masalah diatas, permasalahan dalam penulisan ini adalah menganalisa bagaimana dampak penggunaan tabir surya bagi manusia dan lingkungan serta pengaturan penggunaannya dan bagaimana urgensi larangan penggunaan tabir surya di kawasan wisata bahari Indonesia. Ruang lingkup dalam penelitian ini adalah kajian ilmu hukum lingkungan yang mengkaji mengenai Urgensi Larangan Penggunaan Kosmetik Terhadap Lingkungan Laut Pada Kawasan Wisata Bahari. Pendekatan masalah yang dilakukan dalam penelitian ini adalah pendekatan yuridis normatif yaitu dengan

\footnotetext{
${ }^{8}$ Kadafi, M. (2018, April 11). Abrasi di Bali Disebabkan Kerusakan 7200 Hektare Terumbu Karang. Dipetik Mei 11, 2018, dari www.merdeka.com: https://www.merdeka.com/peristiwa/abrasi-di-bali-disebabkan-kerusakan-7200-hektare-terumbukarang.html

${ }^{9}$ Danovaro, R., Bongiorni, L., Corinaldesi, C., Giovannelli, D., Damiani, E., astolfi, P., et al., "Sunscreens Cause Coral Bleaching by Promoting Viral Infections”, Environmental Health Perspectives, Vol. 116 No. 4 , (2008), hlm 441-447.

10 Tempo.co. (2015, April 11). Kenaikan Suhu Permukaan Laut Ancam Terumbu Karang. Dipetik Mei 11, 2018, dari Tempo.co Web site: https://nasional.tempo.co/read/656918/kenaikan-suhu-permukaan-laut-ancam-terumbu-karang

${ }^{11}$ Danovaro, R., Bongiorni, L., Corinaldesi, C., Giovannelli, D., Damiani, E., astolfi, P., et al. (April 2008). Op.cit.

12 Diaz, J. R. (t.thn.). How to Protect the Skin Without Damaging the Environment. Dipetik Juni 12, 2018, dari www.enenvironment.tau.ac.il: https://en-environment.tau.ac.il/Sustainable_skin_protection_Juliana

13 Isakh, J. (2015, Oktober 26). Tabir Surya dapat 'Membunuh' Terumbu Karang. Dipetik Juni 12, 2018, dari www.cnnindonesia.com: membunuh-terumbu-karang/ https://student.cnnindonesia.com/edukasi/20151026165342-363-87473/tabir-surya-dapat-

${ }^{14}$ Glusac, E. (2018, Mei 3). Hawaii Passes Bill Banning Sunscreen That Can Harm Coral Reefs. Dipetik Mei 10, 2018, dari New York Times Web Site: https://www.nytimes.com/2018/05/03/travel/hawaii-sunscreen-ban.html

${ }^{15}$ Folley, A. (2018, Mei 2). Hawaii Lawmakers Approve Ban on Sunscreens with Chemicals Harmful to Coral Reefs. Dipetik Mei 17, 2018, dari thehill.com: http://thehill.com/business-a-lobbying/385823-hawaii-lawmakers-pass-bill-banningsunscreens-with-chemicals-harmful-to

${ }^{16}$ A. Kadar, "Pengelolaan Kemaritiman Menuju Indonesia Sebagai Poros Maritim Dunia", Jurnal Keamanan Nasional, Vol 1 No.3, (2015), hlm 440.
} 
cara menelaah kaidah-kaidah, norma-norma, aturan-aturan yang berhubungan dengan masalah yang akan diteliti agar diperoleh pemahaman yang jelas tentang pokok bahasan yang diteliti. Sebagai upaya mengumpulkan data yang diperlukan dalam penelitian, akan menggunakan cara pengumpulan data yaitu, studi kepustakaan. Analisis data yang digunakan dalam penelitian ini adalah analisis kualitatif dan kesimpulan dengan metode deduktif yaitu dari peristiwa yang bersifat umum dan berakhir pada kesimpulan yang bersifat khusus.

\section{B. Pembahasan}

\section{Dampak Penggunaan Kosmetik Dan Pengaturannya}

Paparan berkepanjangan radiasi ultraviolet dalam sinar matahari akibat penipisan lapisan ozon dapat menimbulkan dampak bagi kesehatan yang bersifat akut maupun kronis. Dampak tersebut diantaranya terjadi pada kulit, mata, serta sistem kekebalan tubuh. Dampak akut yang paling sering dirasakan adalah kulit terbakar dan menggelapnya warna kulit, sedangkan yang bersifat kronis contohnya adalah kanker kulit. ${ }^{17}$ WHO (World Health Organization) menganjurkan untuk berteduh, memakai pakaian tertutup dan topi lebar, serta menggunakan tabir surya (sunscreen) pada area yang sering terpapar sinar matahari seperti wajah dan tangan sebagai upaya memproteksi diri dari radiasi ultraviolet. ${ }^{18}$ Tabir surya adalah produk yang menggabungkan beberapa bahan yang membantu mencegah radiasi ultraviolet (UV) matahari yang terdiri dari UVA dan UVB. UVB adalah penyebab utama di balik kulit terbakar (sunburn), sementara sinar UVA menembus kulit lebih dalam, menyebabkan kerutan, kulit kendur, dan efek-efek penuaan lainnya (fotoaging). Sinar UVA juga memperburuk efek karsinogenik dari sinar UVB, dan berpotensi sebagai penyebab kanker kulit. ${ }^{19}$

Louisa G. Gordon et al mengevaluasi hasil penelitian yang dilakukan Green et al pada tahun 1993-1997 terhadap masyarakat ras Kaukasia di negara subtropis menemukan penggunaan rutin tabir surya efektif mencegah terjadinya kanker dan tumor kulit secara praktis dan efisien. ${ }^{20}$ Margaret B. Planta dalam ulasan medisnya menyebutkan pertama, penggunaan tabir surya bukan untuk memperpanjang paparan sinar matahari karena justru akan memperbesar risiko kulit terbakar dan kedua, pemakaian ulang tabir surya tanpa berusaha untuk mencari tempat berteduh akan meningkatkan risiko kulit terbakar yang dapat berlanjut menjadi CMM (Cutaneous Malignant Melanoma), ketiga kombinasi penggunaan tabir surya dan pakaian yang tertutup adalah bentuk proteksi terbaik dari radiasi sinar matahari, keempat hendaknya menggunakan tabir surya dengan perlindungan terhadap radiasi UVA dan UVB serta orang dengan risiko tinggi terkena CMM kemungkinan besar mendapatkan perlindungan dengan penggunaan tabir surya berspektrum luas. ${ }^{21}$

Kemampuan tabir surya dalam memberikan perlindungan terhadap UVA dan UVB bervariasi, tergantung pada kandungan bahan aktifnya. Bahan aktif dalam tabir surya ada dua bentuk yakni mineral dan filter kimia. Masing-masing menggunakan mekanisme berbeda untuk melindungi kulit dan menjaga stabilitas di bawah sinar matahari. Tabir surya yang paling umum di pasaran mengandung filter kimia. Produk-produk ini biasanya termasuk

\footnotetext{
17 Santi Listyawati, Sismindari, Sofia Mubarika, Yosi B. Murti, "Aktivitas Kemoprevensi Ekstrak Temu Kunci (Boesenbergia Pandurata) Pada Karsigonesis Kulit Mencit BALB/C Terinduksi Radiasi Ultra Violet”, Proceeding Biology Education Confrence, Vol 9 No. 1, (2012), hlm 612.

18 World Health Organization. (2002). Global Solar UV Index. Dipetik Juni 10, 2018, dari www.who.int: http://www.who.int/uv/publications/en/UVIGuide.pdf

19 Skin Cancer Foundation. (2012, Mei 22). Sunscreen Explained. Dipetik Juni 8, 2018, dari www.skincancer.org: https://www.skincancer.org/prevention/sun-protection/sunscreen/sunscreens-explained

${ }^{20}$ Gordon, L. G., Scuffham, P. A., Pols, J. C., McBride, P., Williams, G. M., \& Green, A. C., "Regular Sunscreen Use is A Cost-Effective Approach to Skin Cancer Prevention in Subtropical Settings", Journal of Investigative Dermatology, Vol. 129 , (2009), hlm 2766-2771.

${ }^{21}$ Planta, M. B., "Sunscreen and Melanoma: Is Our Prevention Message Correct?" Journal of The American Board of Family Medicine, Vol. 24 No. 6 , (2011), hlm 735-739.
} 
kombinasi dari dua hingga enam bahan aktif berikut: oxybenzone, avobenzone, octisalate, octocrylene, homosalate dan octinoxate. Tabir surya mineral menggunakan zinc oxide dan / atau titanium dioxide. Sejumlah produk menggabungkan zinc oxide dengan filter kimia. Tujuan penggabungan tersebut adalah untuk memberikan perlindungan spektrum luas.

Selain bermanfaat, penggunaan tabir surya juga menimbulkan kekhawatiran terkait dengan kandungan filter kimianya. EWG (Environmental Working Group) telah meninjau data tentang paparan terhadap manusia dan toksisitas bahan-bahan kimia tabir surya yang paling umum digunakan. Oxybenzone merupakan bahan kimia yang paling dikhawatirkan dan ditambahkan kepada hampir 65 persen tabir surya non-mineral yang terdaftar dalam database tabir surya EWG 2018. Hasil penelitian Jirot Sindhvananda et al yang dilakukan selama tahun 2000-2009 di Bangkok menunjukkan bahwa oxybenzone merupakan penyebab paling umum terjadinya PACD (Photo Allergic Contact Dermatitis) dan reaksi alergi lainnya. Marya Ghazipura et al dalam penelitiannya tentang toksisitas sistem reproduksi oleh oxybenzone menemukan paparan oxybenzone dalam jumlah besar dapat mengganggu sistem endokrin dan berhubungan dengan peningkatan berat lahir bayi laki-laki; namun justru menurunkan berat lahir bayi perempuan dan masa kehamilan bayi laki-laki. ${ }^{22}$ Bahan kimia lain yang patut diwaspadai adalah octinoxate.

Paparan octinoxate, begitupula oxybenzone, berhubungan dengan kejadian endometriosis pada wanita; serta berpotensi merusak DNA manusia karena sifat keduanya yang mutagenik dan karsinogenik. ${ }^{23}$ Di samping dapat membahayakan kesehatan, bahan kimia dalam tabir surya ternyata berbahaya bagi ekosistem laut. Produksi dan konsumsi produk perawatan diri serta tabir surya saat ini terus meningkat secara global hingga mencapai level di luar perkiraan dan berpotensi mengkontaminasi lingkungan. Menurut Wilkinson dalam jurnal Roberto Danovaro et al, penjualan produk-produk tersebut berhubungan dengan ekspansi wisata di daerah terumbu karang yang semakin berkembang. ${ }^{24}$ Dari penelitian Daughten dan Ternes serta penelitian Giokas, kandungan kimia dalam produk tabir surya diketahui telah mencapai level yang sudah dapat terdeteksi baik di air tawar maupun air laut. ${ }^{25}$ Sebagaimana kita ketahui bahwa objek wisata bahari merupakan tempat di mana tabir surya digunakan secara masif oleh para wisatawan, mengingat paparan sinar matahari yang sangat tinggi di sana. Bahan kimia dalam tabir surya akan luruh terbilas oleh air, sehingga semakin banyak jumlah wisatawan, maka semakin tinggi pula kandungan bahan kimia terakumulasi dalam air laut. Penelitian in situ yang dilakukan oleh Danovaro et al pada tahun 2003-2007 di beberapa area terumbu karang yaitu: 1) Siladen, Laut Celebes (Samudera Pasifik, Indonesia); 2) Akumal, Laut Karibia (Mexico, Samudera Atlantik); 3) Phuket, Laut Andaman (Thailand); 4) Ras Mohammed, Laut Merah (Mesir) menunjukkan bahwa tabir surya berperan dalam pemutihan terumbu karang secara cepat dan menyeluruh, bahkan pada konsentrasi yang paling rendah; terutama yang mengandung oxybenzone. Hal ini disebabkan oleh bahan filter organik dalam tabir surya yang mampu menginduksi siklus virus litik pada alga Zooxanthellae dengan infeksi laten. ${ }^{26}$

Pada tahun 2015 lembaga Haereticus Environment Laboratory melakukan survei di Teluk Trunk, St. John, yang dikunjungi oleh 2.000-5.000 perenang setiap hari. Mereka memperkirakan sekitar 6.000 pounds tabir surya mengendap pada terumbu karang setiap

\footnotetext{
${ }^{22}$ Ghazipura, M., McGowan, R., Arslan, A., \& Hossain, T., "Exposure to Benzophenone-3 and Reproductive Toxicity: a Systematic Review of Human and Animal Studies", Reproductive Toxicology Vol. 73 , (2017), hlm 175-183.

${ }^{23}$ Oxybenzone Octinoxate Health Threats. (t.thn.). Dipetik Juni 11, 2018, dariwww.bantoxicsunscreens.com:https://bantoxicsunscreens.com/wpcontent/uploads/2018/02/Oxybenzone-OctinoxateHealth-Threats.pdf

${ }^{24}$ Danovaro, R., Bongiorni, L., Corinaldesi, C., Giovannelli, D., Damiani, E., astolfi, P., et al. (April 2008). Op.cit.

${ }^{25}$ Ibid.

${ }^{26}$ Ibid.
} 
tahunnya. Di tahun yang sama, ditemukan rata-rata 412 pounds tabir surya mengendap setiap hari pada karang di Teluk Hanauma, sebuah tempat snorkeling populer dengan jumlah pengunjung mencapai 2.600 orang per hari. ${ }^{27}$ Dalam penelitian tersebut, Downs et al menyelidiki efek oxybenzone terhadap bentuk larva (planula) dari terumbu karang Stylophora pistillata dan menyimpulkan bahwa oxybenzone sebagai polutan terbesar pada terumbu karang yaitu dengan mengganggu sistem endokrin serta merusak DNA larva karang. Oxybenzone meningkatkan kemungkinan perginya Zooxanthellae dalam jumlah besar dari terumbu karang, menyebabkan karang kehilangan warna dan mempengaruhi kemampuan karang untuk bereproduksi, serta menurunkan populasi karang secara terus menerus. ${ }^{28}$ Bahkan disebutkan bahwa setetes oxybenzone dapat menghancurkan terumbu karang seluas enam setengah kali kolam renang olimpiade. ${ }^{29}$ Pada bagian pendahuluan disebutkan bahwa Hawaii telah meloloskan Rancangan Undang Undang berisi larangan distribusi tabir surya dengan kandungan oxybenzone dan octinoxate yang tertuang dalam dokumen Senate Bill No. 2571, berupa A Bill for An Act, Relating to Water Pollution. Hal tersebut dilatarbelakangi oleh sebagaimana tercantum dalam Bagian 1 Rancangan Undang-Undang, "Badan legislatif menemukan bahwa dua bahan kimia yang terkandung dalam banyak tabir surya, oxybenzone dan octinoxate, memiliki dampak berbahaya yang signifikan terhadap lingkungan laut Hawaii dan ekosistem yang ada, termasuk terumbu karang yang melindungi garis pantai Hawaii." 30

Badan legislatif selanjutnya menemukan bahwa pencemaran lingkungan oxybenzone dan octinoxate berlangsung di perairan pesisir Hawaii, karena kontaminasi terus-menerus yang berlangsung setiap hari oleh perenang dan pengunjung pantai. Dengan demikian, tujuan dari undang-undang ini guna melestarikan ekosistem laut, termasuk terumbu karang serta melarang penjualan produk perlindungan matahari tabir surya ultraviolet personal yang mengandung oxybenzone dan octinoxate di Hawaii sebagai upaya mengurangi kontaminasi tersebut secara aktif. ${ }^{31}$ Meskipun peraturan tersebut akan menjadi undang-undang pertama di dunia yang melarang penggunaan tabir surya berkandungan oxybenzone dan octinoxate pada wisata bahari, namun pelarangan serupa telah diterapkan di beberapa tujuan wisata populer, salah satunya di Taman Wisata Bahari (Marine Ecoparks) Mexico. Di objek wisata tersebut, hanya tabir surya dengan kandungan titanium dioxide dan zinc oxide yang diizinkan untuk digunakan. ${ }^{32}$

\section{Urgensi Larangan Penggunaan Kosmetik Pada Kawasan Wisata Bahari Di Indonesia}

Bahan tabir surya yang dibenarkan dalam kosmetika diatur dalam Peraturan Kepala Badan Pengawas Obat dan Makanan Republik Indonesia Nomor 18 Tahun 2015 tentang Persyaratan Teknis Bahan Kosmetika. Dalam peraturan tersebut, bahan tabir surya merupakan bahan dalam sediaan kosmetika tabir surya yang bertujuan melindungi kulit dari efek yang merugikan akibat radiasi sinar ultraviolet. Bahan tabir surya dapat ditambahkan ke dalam sediaan kosmetik lainnya dengan batasan dan persyaratan sesuai dengan persyaratan dalam peraturan ini. ${ }^{33}$ Kadar maksimum bahan oxybenzone atau dengan nama lain benzophenone-3 dalam kosmetika sebesar 10 persen dan harus disertai dengan penandaan atau peringatan "Mengandung Oxybenzone". Peringatan tidak diperlukan jika kadar oxybenzone 0,5 persen

\footnotetext{
${ }^{27}$ Glusac, E. (2018, Mei 3). Op.cit.

${ }^{28}$ Danovaro, R., Bongiorni, L., Corinaldesi, C., Giovannelli, D., Damiani, E., astolfi, P., et al. (April 2008). Op.cit.

${ }^{29}$ Isakh, J. (2015, Oktober 26). Op.cit.

${ }^{30}$ Senate Bill No. 2571, A Bill for An Act Relating to Water Pollution.

${ }^{31}$ Ibid.

32 Ecopark, X. (t.thn.). Frequently Asked Questions. Dipetik Juni 18, 2018, dari www.xcaret.com: http://www.xcaret.com/faqs.php

33 Peraturan Kepala Badan Pengawas Obat dan Makanan Republik Indonesia Nomor 18 Tahun 2015 tentang Persyaratan Teknis Bahan Kosmetika.
} 
atau kurang serta bila digunakan hanya untuk tujuan perlindungan. Untuk octinoxate atau dengan nama lain octyl methoxycinnamate, kadar maksimum dalam kosmetika juga sebesar 10 persen tanpa harus disertai peringatan. ${ }^{34}$ Menurut penulis, pencantuman peringatan kandungan oxybenzone dalam sediaan kosmetika adalah langkah awal untuk menggugah kesadaran dan kewaspadaan pengguna tabir surya terhadap bahaya bahan tersebut. Sayangnya langkah ini masih jauh dari efektif, mengingat tingkat pengetahuan masyarakat tentang bahaya bahan filter kimia dalam tabir surya masih terbilang rendah. ${ }^{35}$ Meskipun tercantum pada kemasan, peringatan biasanya ditulis dalam ukuran kecil, sehingga sulit dibaca atau malah tidak dibaca sama sekali.

Seperti disebutkan dalam pendahuluan, bahwa kunjungan wisatawan di Bali terus bertambah setiap tahunnya. Tingginya jumlah kunjungan wisatawan akan berbanding lurus dengan penggunaan tabir surya yang selanjutnya berpotensi memperbesar jumlah bahan filter kimia yang larut di air laut. Akumulasi oxybenzone dan octinoxate di perairan Bali dikhawatirkan memicu terjadinya pemutihan karang hingga merusak terumbu karang. ${ }^{36}$

Sumber daya terumbu karang merupakan salah satu sumber pendapatan utama dan bagian dari hidup nelayan di Indonesia. Terumbu karang juga mempunyai nilai estetika sangat tinggi yang dapat dimanfaatkan sebagai objek wisata dalam meningkatkan devisa negara. ${ }^{37}$ Terumbu karang pun mempunyai fungsi yang sangat penting sebagai tempat memijah, mencari makanan, daerah asuhan dari berbagai biota laut dan sebagai sumber plasma nutfah serta merupakan sumber berbagai makanan dan bahan baku substansi bioaktif yang berguna dalam bidang farmasi dan kedokteran. Fungsi terumbu karang yang tidak kalah penting adalah sebagai sarana pendidikan dan penelitian. ${ }^{38}$ Angka kejadian pemutihan karang khususnya di Provinsi Bali belum diketahui secara pasti karena pendataan masih terus dilakukan hingga saat ini. ${ }^{39}$ Selain pemerintah, pihak yang aktif melakukan pendataan ialah LSM peduli lingkungan di antaranya Coral Triangle Center (CTC) dan Reef Check Foundation Indonesia, bekerja sama dengan komunitas scubadiving yang ada di Bali. Pendataan juga dibantu oleh pencitraan satelit yang dilakukan National Oceanic and Atmopheric Administration (NOAA) melalui program Coral Reef Watch. ${ }^{40}$ Salah satu contoh pemutihan karang yang terpantau terjadi di Bali Selatan, meliputi Sanur, Serangan hingga Nusa Dua.Dalam kasus tersebut, pemutihan karang lebih disebabkan oleh kenaikan suhu air laut. ${ }^{41}$ Namun tidak tertutup kemungkinan adanya kontribusi penggunaan tabir surya oleh wisatawan. Terlebih lagi tabir surya yang banyak dijual dan populer dipakai oleh pengunjung wisata pantai umumnya masih merupakan produk impor serta mengandung kedua bahan filter kimia di atas. ${ }^{42}$

Undang-Undang Dasar Negara Republik Indonesia Tahun 1945 telah menegaskan bahwa tidak boleh ada kebijakan yang bertentangan dengan ketentuan mengenai wawasan

\footnotetext{
${ }^{34}$ Ibid.

${ }^{35}$ Sartika Sri Wulandari, Max R.J. Runtuwenw, Defny S. Wewengkang, “Aktivitas Perlindungan Tabir Surya Secara In Vito dan In Vivo dari Krim Ekstrak Etanol Daun Soyogik (Saravia Bracteosa DC)”, Jurnal Ilmiah Farmasi, Vol 6 No. 3, (2017), hlm 153-154.

${ }^{36}$ Bambang Pramudyanto, "Pengendalian Pencemaran dan Kerusakan di Wilayah Pesisir", Jurnal Lingkungan Widyaiswara, Vol 1 No. 4, (2014), hlm 25-26.

${ }^{37}$ Kementerian Lingkungan Hidup. (t.thn.). Selamatkan Terumbu Karang Sekarang. Dipetik Mei 11, 2018, dari www.menlh.go.id: http://www.menlh.go.id/selamatkan-terumbu-karang-sekarang/

${ }^{38}$ Ibid.

${ }^{39}$ Daifudin Salim, "Pengelolaan Ekosistem Terumbu Karang Akibat Pemutihan (Bleaching) Dan Rusak”, Jurnal Kelautan, Vol 5 No. 2, (2012), hlm 143.

${ }^{40}$ Coral Bleaching Indonesia. (t.thn.). Dipetik Juni 19, 2018, dari www.reefcheck.or.id: http://reefcheck.or.id/bleaching/

41 Tempo.co. (2016, Juni 8). Coral Bleaching Ancam Terumbu Karang Bali. Dipetik Juni 19, 2018, dari www.nasional.tempo.co: https://nasional.tempo.co/read/778028/coral-bleaching-ancam-terumbu-karang-bali

${ }^{42}$ Aditia Syaprillah, "Penegakan Hukum Administrasi Lingkungan Melalui Instrumen Pengawasan", Jurnal Bina Hukum Lingkungan, Vol 1 No.1, (2016), hlm 100.
} 
lingkungan dan prinsip pembangunan berkelanjutan yang tercantum di dalamnya. ${ }^{43}$ Pasal 33 ayat (4) UUD 1945 menyebutkan bahwa "Perekonomian nasional diselenggarakan berdasar atas demokrasi ekonomi dengan prinsip kebersamaan, efisiensi-berkeadilan, berkelanjutan, berwawasan lingkungan, kemandirian, serta dengan menjaga keseimbangan, kemajuan, dan kesatuan ekonomi nasional". ${ }^{44}$

Menurut Rachel Carson dalam bukunya yang berjudul Silent Spring, di dalam konsep pembangunan berkelanjutan (sustainable development), proses pembangunan atau perkembangan (development) diharapkan dapat memenuhi kebutuhan masa sekarang tanpa membahayakan kemampuan generasi yang akan datang untuk memenuhi kebutuhannya dalam memanfaatkan potensi sumber daya alam untuk kehidupan. Pembangunan berkelanjutan yang berwawasan lingkungan hidup dapat dirumuskan sebagai upaya sadar dan terencana yang memadukan lingkungan, termasuk sumber dayanya, ke dalam proses pembangunan yang menjamin kemampuan, kesejahteraan, dan mutu hidup generasi masa sekarang dan generasi yang akan datang. Formulasi Brundtland Report, mengandung dua elemen pokok dalam pembangunan berkelanjutan. Pertama, konsep kebutuhan yakni kebutuhan generasi masa kini dan mendatang untuk hidup sejahtera, terutama kebutuhan hidup bagi orang-orang miskin dan komunitas-komunitas tertinggal yang harus mendapat prioritas utama dalam pembangunan. Kedua, konsep pembatasan yakni terhadap pemaksaan yang dilakukan oleh negara, korporasi, ataupun masyarakat atas kemampuan lingkungan untuk memenuhi tuntutan kebutuhan sekarang dan masa yang akan datang. ${ }^{45}$ Keduanya berhubungan dengan sistem kehidupan yang berdimensi ruang dan waktu. Ruang hidup ialah lingkungan di mana manusia hidup, bergaul, dan membangun penghidupan yang layak bagi kemanusiaan, serta ruang peradaban di mana masyarakat manusia membangun peradaban kolektifnya. Dimensi waktu, yaitu masa kini dan masa depan yang dipahami sebagai suatu kelanjutan dan kesinambungan kehidupan, bukan saja bagi komunitas masyarakat yang bersangkutan, tetapi juga bagi manusia dan kemanusiaan seluruhnya. ${ }^{46}$ Dalam konsep pengelolaan lingkungan hidup, Undang-Undang Republik Indonesia Nomor 32 tahun 2009 tentang Perlindungan dan Pengelolaan Lingkungan Hidup diberikan nama perlindungan dan pengelolaan lingkungan hidup. Ini menunjukkan adanya jaminan terhadap perlindungan selain pemanfaatan lingkungan hidup. Menurut pasal 44 undang-undang $a$ quo, perlindungan dan pengelolaan lingkungan hidup meliputi unsurunsur: a) Perencanaan; b) Pemanfaatan; c) Pengendalian; d) Pemeliharaan; e) Pengawasan; f) Pengelolaan lingkungan hidup.

Mencuatnya isu pemutihan karang akibat penggunaan tabir surya di dunia internasional perlu mendapat perhatian pemerintah. Kontaminasi bahan kimia adalah proses yang akan terus terjadi dan berdampak buruk jika tidak dihentikan secara aktif. Sekalipun penggunaan tabir surya bukan faktor utama penyebab pemutihan karang, namun kita masih memiliki peluang (opportunity) untuk melindungi terumbu karang dari kerusakan yang lebih lanjut, yaitu bahwa kadar bahan filter kimia tersebut merupakan variabel yang dapat dikontrol dengan membatasi atau bahkan melarang penggunaannya. Kekosongan peraturan tersebut harus dicari jalan keluarnya. ${ }^{47}$

Menyikapi perkembangan dan penemuan tentang lingkungan hidup yang lahir dari berbagai penelitian terbaru, kita harus mampu beradaptasi termasuk di bidang hukum.

\footnotetext{
${ }^{43}$ Kartiko Harnadi, "Model Penguasaan Tanah Oleh Masyarakat Desa Margosari dan Penyelesainnya Pada Kawasan Hutan Lindung Register 22 Way Waya Kabupaten Pringsewu", Jurnal Cepalo, Vol. 2 No.2, (2018), hlm 86.

${ }^{44}$ J. Assidiqie, (2009). Green Constitution: Nuansa Hijau Undang-Undang Dasar Negara Republik Indonesia Tahun1945. Jakarta: Rajawali Pers. hlm 141.

${ }^{45}$ Ahmad Jazuli, "Pengakuan Hukum Penataan Ruang Dalam Rangka Mewujudkan Pembangunan Berkelanjutan", Jurnal Rechtsvinding, Vol. 6 No.2, (2017), hlm 267-268

${ }^{46}$ Ibid. hlm 140.

47 Zulfikli Aspan, "Perlindungan Hukum Terhadap Terumbu Karang Di Taman Nasional Taka Bonerata (TNT)", Jurnal Hukum Lingkungan Indonesia, Vol. 2 No.2, (2015), hlm 77-78.
} 
Adaptasi yang dapat kita lakukan adalah dengan membuat peraturan yang melarang penggunaan tabir surya pada kawasan wisata bahari di Indonesia, mengingat hal tersebut belum diatur sama sekali. Terumbu karang yang sehat dan berfungsi optimal akan berdampak positif melalui terjaganya kondisi pantai dan pulau dari abrasi, terpenuhinya ikan tangkapan nelayan, tersedianya bahan baku industri farmasi dan kedokteran, peningkatan devisa negara dari sektor wisata, serta tersedianya sarana pendidikan dan penelitian. Melalui pelarangan penggunaan tabir surya pada kawasan wisata bahari, maka jumlah oxybenzone dan octinoxate terlarut dalam air laut dapat diminimalisir, sehingga risiko pemutihan karang berkurang dan kelestariannya dapat terjaga. Keseluruhan hal di atas akan meningkatkan kesejahteraan masyarakat.

Larangan penggunaan tabir surya harus mencantumkan jenis tabir surya apa saja yang tidak diperbolehkan serta dibatasi hanya berlaku di kawasan wisata bahari. Hal ini disebabkan tidak semua tabir surya berbahaya bagi terumbu karang. Tabir surya dengan bahan aktif zinc oxide dan titanium dioxide aman bagi karang, dengan catatan bukan dalam bentuk partikel nano. Oleh karena itu, dapat digunakan sebagai alternatif dalam memperoleh manfaat perlindungan dari radiasi sinar UV. Dengan demikian, manusia dapat tetap menjaga kesehatannya sebagai syarat mencapai kesejahteraan tanpa merusak lingkungan hidup. Langkah di atas sesuai dengan teori hukum progresif yang dikemukakan oleh Prof. Satjipto Rahardjo, dengan asumsi bahwa hukum dibuat untuk manusia, dimana hukum adalah institusi yang bertujuan mengantarkan manusia kepada kehidupan yang adil, sejahtera dan membuat manusia bahagia. Ia memenuhi kriteria hukum progresif antara lain bertujuan mencapai kesejahteraan dan kebahagiaan manusia; memuat kandungan moral kemanusiaan yang sangat kuat; membebaskan dan meliputi dimensi yang sangat luas; serta bersifat kritis dan fungsional dengan terus melihat kekurangan yang ada dan segera menemukan solusinya. Selain itu, ia juga sejalan dengan hukum responsif yang dikemukakan oleh Philipe Nonet dan Philip Selznick; pembuatan larangan merupakan adaptasi di bidang hukum yang bertanggung jawab, selektif dan tidak serampangan; sebagai respon dari perkembangan dan perubahan dalam kehidupan, khususnya lingkungan hidup, yang didasarkan pada berbagai riset, atau fakta dan data.

Penegakan hukum lingkungan tidak hanya harus bersifat represif namun juga lebih utama bersifat preventif. Salah satu yang menyebabkan lemahnya penataan terhadap peraturan perundang-undangan dan standar-standar lingkungan adalah lemahnya pengawasan dan mindset dari aparatur pemerintah. ${ }^{48}$

\section{Penutup}

Berdasarkan hasil penelitian dan pembahasan tersebut diatas, maka penulis menarik kesimpulan yakni Tingginya kunjungan wisata bahari berbanding lurus dengan penggunaan tabir surya yang dapat menyebabkan naiknya kandungan oxybenzone dan octinoxate dalam air laut. Oxybenzone dan octinoxate dalam kadar paling rendah dapat menyebabkan pemutihan karang dan merusak terumbu karang. Penggunaan tabir surya dengan kandungan oxybenzone dan octinoxate telah dilarang di Taman Wisata Bahari Mexico dan distribusinya akan dilarang di Hawaii melalui Rancangan Undang-Undang atau Senate Bill No. 2571. Lalu kerusakan terumbu karang mengancam kesejahteraan manusia. Di Indonesia, belum ada peraturan yang melarang penggunaan tabir surya yang dapat membahayakan terumbu karang. Oleh karena itu, mengacu pada teori hukum progresif, larangan penggunaan tabir surya khusus pada kawasan wisata bahari dinilai urgen sebagai bentuk hukum yang dibuat untuk manusia dan solusi bagi kekosongan hukum terkait perlindungan terumbu karang. Adaptasi hukum yang selektif dan bertanggung jawab serta didasari pada fakta dan data di bidang lingkungan hidup

\footnotetext{
${ }^{48}$ M. Akib, (2015). Penegakan Hukum Lingkungan dalam Perspektif Holistik-Ekologis. Yogyakarta: Graha Ilmu. hlm. 27.
} 
ini juga sejalan dengan teori hukum responsif. Saran dalam penelitian ini yakni pemerintah hendaknya membuat peraturan yang melarang penggunaan tabir surya pada kawasan wisata bahari sebagai bentuk tindakan prevetif dalam menjaga kelestarian lingkungan, khususnya terumbu karang. Lalu Pemerintah daerah setempat hendaknya melakukan sosialisasi bahaya kerusakan terumbu karang dan memperkenalkan jenis tabir surya ramah lingkungan disertai dengan pengawasan dan pembinaan yang bekerja sama dengan berbagai pihak mulai dari pihak bandara, agen perjalanan, hotel, restoran, penggiat lingkungan hidup serta masyarakat. Selain itu hendaknya pemerintah setempat menggali potensi produsen perawatan kulit lokal untuk memproduksi tabir surya yang ramah lingkungan.

\section{Daftar Pustaka}

A. Buku

Akib, M. (2015). Penegakan Hukum Lingkungan dalam Perspektif Holistik-Ekologis. Yogyakarta: Graha Ilmu.

Assidiqie, J. (2009). Green Constitution: Nuansa Hijau Undang-Undang Dasar Negara Republik Indonesia Tahun1945. Jakarta: Rajawali Pers.

. (2016). The Best Direct Foreign Tourist Arrival to Bali in January-December. Denpasar: Dinas Pariwisata Provinsi Bali.

Nonet, P., \& Selznick, P. (2013). Hukum Responsif. Bandung: Penerbit Nusa Media.

Rahardjo, S. (2008). Biarkan Hukum Mengalir. Jakarta: Penerbit Buku Kompas. . (2009). Hukum Progresif: Sebuah Sintesa Hukum Indonesia. Yogyakarta: Genta Publishing.

Sumarja, F. (2012). Problematika Kepemilikan Tanah bagi Orang Asing. Bandar Lampung: Indepth Publishing.

B. Jurnal

Arimbawa, Wahyudi, and I Komang Gede Santhyasa. "Perpektif Ruang Sebagai Entitas Budaya Lokal Orientasi Simbolik Ruang Masyarakat Tradisional Desa Adat." Local Wisdom-Jurnal Ilmiah Online, Issn: 2086-3764 II, no. 2010, 2010: 1-9.

Arizona, Mercy, and A. Karim Zulkarnain. "Optimasi Formula Dan Uji Aktivitas Secara In Vitro Lotion O/W Ekstrak Etanolik Rimpang Temu Mangga (Curcuma Mangga Val. Dan Van Zijp) Sebagai Tabir Surya." Majalah Farmaseutik 14, no. 1, 2018: 29-41. https://doi.org/10.22146/farmaseutik.v14i1.41926.

Dahuri, Rokhimin. "Pengelolaan Ruang Wilayah Pesisir Dan Lautan Seiring Dengan Pelaksanaan Otonomi Daerah." Jurnal Sosial Dan Pembangunan 17, no. 2, 2001: 139-71. https://doi.org/https://doi.org/10.29313/mimbar.v17i2.38.

Ernawati, Ni Made. "Pengaruh Pariwisata Terhadap Kehidupan Sosial Budaya Pesisir Di Kawasan Taman Nasional Bali Barat Dan Taman Wisata Pulau Menjangan." Sabda: Jurnal Kajian Kebudayaan 6, no. 1, 2011: 69-74. https://doi.org/10.14710/sabda.v6i1.13307.

Gordon, Louisa G., Paul A. Scuffham, Jolieke C. van der Pols, Penelope McBride, Gail M. Williams, and Adèle C. Green. "Regular Sunscreen Use Is A Cost-Effective Approach To Skin Cancer Prevention In Subtropical Settings." Journal of Investigative Dermatology 129, no. 12, 2009: 2766-71. https://doi.org/10.1038/jid.2009.141.

Harnadi, Kartiko. "Model Penguasaan Tanah Oleh Masyarakat Desa Margosari Dan Penyelesaiaannya Pada Kawasan Hutan Lindung Register 22 Way Waya Kabupaten Pringsewu." Cepalo 2, no. 2, 2019: 85-92. https://doi.org/10.25041/cepalo.v2no2.1765.

Jazuli, Ahmad. "Dinamika Hukum Lingkungan Hidup Dan Sumber Daya Alam Dalam Rangka Pembangunan Berkelanjutan (The Law Dynamics On The Environmental And Natural Resources In Order To Sustainable Development)." RechtsVinding Media Pembinaan Hukum Nasional 4, no. 2, 2015: 181-97. 
Kadar, A. "Pengelolaan Kemaritiman Menuju Indonesia Sebagai Poros Maritim Dunia." Jurnal Keamanan Nasional 1, no. 3, 2015: 427-42.

Kim, So Woong. "Kebijakan Hukum Pidana Dalam Upaya Penegakan Hukum Lingkungan Hidup." Dinamika Hukum 2, no. 4, 2010: 415-27.

Lawang, Marcella. "Penegakan Hukum Terhadap Pencemaran Dan Perusakan Lingkungan Objek Wisata Berdasarkan Undang-Undang Nomor 10 Tahun 2009." LEX CRIMEN 4, no. 7, 2015 : $58-66$.

Pramudyanto, Bambang. "Pengendalian Pencemaran Dan Kerusakan Di Wilayah Pesisir." Jurnal Lingkar Widyaiswara, no. 4, 2014: 21-40.

Syaprillah, Aditia. "Penegakan Hukum Administrasi Lingkungan Melalui Instrumen Pengawasan.” Bina Hukum Lingkungan 1, no. 1, 2016: 99-113. https://doi.org/10.24970/jbhl.v1n1.8.

Thistle, David, Kevin M. Sherman, Oleksander Oleksandr Holovachov, Sven Boström, Kamran Safi, Marcus Vinicius Cianciaruso, Rafael D. Loyola, et al. "The Contribution Of Deep-Sea Macrohabitat Heterogeneity To Global Nematode Diversity." Marine Biodiversity, 2014. https://doi.org/10.1017/CBO9781107415324.004.

Tuma, J. M., \& Pratt, J. M. (1982). Clinical child psychology practice and training: A survey. Vdots of Clinical Child \& Adolescent Psychology, 137(August 2012), 37-41. http://doi.org/10.1037/a0022390, 120-130. Gobry, F. (1999). \{T\}his is a title. \{M\}y Journal, 1, S. E. (1980). The Age of Reform 1250-1550.and Religious History of Late Medieval and Reform .... Retrieved from http://scholar.google.com/scholar?hl=en\&btnG=Search\&q=intitle:THE+AGE+OF+REFOR $\mathrm{M}+1250-1550 \# 2 \% 5 \mathrm{Cnhttp}: / /$ scholar.google.com/scholar?hl=en\&btnG=Se Osment, 525-534. http://doi.org/10.1037/0022-0663.100.3.525 Caprara, G., \& Fida, R. (2008). Longitudinal analysis of the role of perceived self-efficacy for self-regulated learning in academic continuance and achievement. ... of Educational ..., 100(3), logic and mathematics in the twentieth century. ... Philosophy. London and New York: Routledge. http://doi.org/10.4324/9780203029473 Shanker, S. (2003). Philosophy of science, J. (1998). Routledge History of Philosophy III. Philosophy. London and New York: Routledge. http://doi.org/10.4324/9780203062272 Marenbon, 88-96. http://doi.org/10.1037//00333204.39.1.88 Pole, N., \& Ablon, J. (2002). Ideal control mastery technique correlates with change in a single case. Theory, Research, Practice ..., 39(1), et al. "Epistemology And Uncertainty: A Follow-Up Study With Third-Year Medical Students." Family Medicine, 2012.

Zainuddin, Sulthan, Endriatmo Soetarto, Soeryo Adiwibowo, and Nurmala K Panjaitan. "Kontestasi Kekuasaan Dalam Pengelolaan SDA." Jurnal Academica Fisip Untad 2, no. 2, 2010: 455-68.

C. Internet

Antara, A. (2018, Januari 27). Jumlah Kunjungan Turis ke Bali Capai 5,7 Juta Orang. Dipetik Mei 11, 2018, dari www.lifestyle.okezone.com: https://lifestyle.okezone.com/read/2018/01/27/406/1850973/jumlah-kunjungan-turis-ke-balicapai-5-7-juta-orang.

Antara, CNN Indonesia. (2017, Agustus 29). Kerusakan Terumbu Karang di Indonesia Mencapai 46 Persen. Dipetik Mei 11, 2018, dari Web site CNN Indonesia: https://www.cnnindonesia.com/gaya-hidup/20170829125301-269-238068/kerusakanterumbu-karang-di-indonesia-mencapai-46-persen.

Coral Bleaching Indonesia. (t.thn.). Dipetik Juni 19, 2018, dari www.reefcheck.or.id: http://reefcheck.or.id/bleaching/.

Diaz, J. R. (t.thn.). How to Protect the Skin Without Damaging the Environment. Dipetik Juni 12, 2018, dari www.en-environment.tau.ac.il: https://enenvironment.tau.ac.il/Sustainable_skin_protection_Juliana.

Ecopark, X. Frequently Asked Questions. Dipetik Juni 18, 2018, dari www.xcaret.com: http://www.xcaret.com/faqs.php. 
Environmental Working Group. (2018). THe Trouble with Ingredients in Sunscreens. Dipetik Juni 10, 2018, dari www.ewg.org: https://www.ewg.org/sunscreen/report/the-trouble-withsunscreen-chemicals/\#.WxyxJ7k0_YM.

Folley, A. (2018, Mei 2). Hawaii Lawmakers Approve Ban on Sunscreens with Chemicals Harmful to Coral Reefs. Retrieved Mei 17, 2018, from thehill.com: http://thehill.com/business-a-lobbying/385823-hawaii-lawmakers-pass-bill-banningsunscreens-with-chemicals-harmful-to.

Glusac, E. (2018, Mei 3). Hawaii Passes Bill Banning Sunscreen That Can Harm Coral Reefs. Retrieved Mei 10, 2018, from New York Times Web Site: https://www.nytimes.com/2018/05/03/travel/hawaii-sunscreen-ban.html.

Isakh, J. (2015, Oktober 26). Tabir Surya dapat 'Membunuh' Terumbu Karang. Dipetik Juni 12, 2018, dari www.cnnindonesia.com: https://student.cnnindonesia.com/edukasi/20151026165342-363-87473/tabir-surya-dapatmembunuh-terumbu-karang/.

Kadafi, M. (2018, April 11). Abrasi di Bali Disebabkan Kerusakan 7200 Hektare Terumbu Karang. Retrieved Mei 11, 2018, from www.merdeka.com: https://www.merdeka.com/peristiwa/abrasi-di-bali-disebabkan-kerusakan-7200-hektareterumbu-karang.html.

Kementerian Lingkungan Hidup. (t.thn.). Selamatkan Terumbu Karang Sekarang. Dipetik Mei 11, 2018, dari www.menlh.go.id: http://www.menlh.go.id/selamatkan-terumbu-karangsekarang/.

Marboen, A. P. (2015, Maret 27). Garis Pantai Indonesia Terpanjang Kedua di Dunia. Retrieved Juni 4, 2018, from www.antaranews.com: https://www.antaranews.com/berita/487732/garispantai-indonesia-terpanjang-kedua-di-dunia.

Oxybenzone Octinoxate Health Threats. (n.d.). Retrieved Juni 11, 2018, from www.bantoxicsunscreens.com: https://bantoxicsunscreens.com/wpcontent/uploads/2018/02/Oxybenzone-Octinoxate-Health-Threats.pdf.

Skin Cancer Foundation. (2012, Mei 22). Sunscreen Explained. Dipetik Juni 8, 2018, dari www.skincancer.org: https://www.skincancer.org/prevention/sunprotection/sunscreen/sunscreens-explained.

Tempo.co. (2016, Juni 8). Coral Bleaching Ancam Terumbu Karang Bali. Dipetik Juni 19, 2018, dari www.nasional.tempo.co: https://nasional.tempo.co/read/778028/coral-bleaching-ancamterumbu-karang-bali.

Tempo.co. (2015, April 11). Kenaikan Suhu Permukaan Laut Ancam Terumbu Karang. Retrieved Mei 11, 2018, from Tempo.co Web site: https://nasional.tempo.co/read/656918/kenaikansuhu-permukaan-laut-ancam-terumbu-karang.

World Health Organization. (2002). Global Solar UV Index. Dipetik Juni 10, 2018, dari www.who.int: http://www.who.int/uv/publications/en/UVIGuide.pdf 
